\title{
PEMBELAJARAN FISIKA MENGGUNAKAN INKUIRI TERBIMBING DENGAN METODE EKSPERIMEN DAN PROYEK DITINJAU DARI KREATIVITAS DAN KEMAMPUAN BERPIKIR KRITIS SISWA
}

\author{
Purwandari $^{1}$, Widha Sunarno ${ }^{2}$, Cari $^{3}$ \\ ${ }^{1}$ Program Studi Magister Pendidikan Sains FKIP Universitas Sebelas Maret \\ Surakarta, 57126, Indonesia \\ purwandari16@gmail.com \\ ${ }^{2}$ Program Studi Magister Pendidikan Sains FKIP Universitas Sebelas Maret \\ Surakarta, 57126, Indonesia \\ widhasunarno@staff.uns.ac.id \\ ${ }^{3}$ Program Studi Magister Pendidikan Sains FKIP Universitas Sebelas Maret \\ Surakarta, 57126, Indonesia \\ cari@staff.uns.ac.id
}

\begin{abstract}
Abstrak
Tujuan penelitian: 1). Mengetahui adakah perbedaan hasil belajar antara siswa yang diberi pembelajaran dengan pendekatan inkuiri terbimbing menggunakan metode eksperimen dan metode proyek. 2). Mengetahui adakah perbedaan hasil belajar antara siswa yang memiliki kemampuan berpikir kritis tinggi dan kemampuan berpikir kritis rendah. 3). Mengetahui adakah perbedaan hasil belajar antara siswa yang memiliki kreativitas tinggi dan kreativitas rendah. 4). Mengetahui adakah interaksi antara pendekatan inkuiri terbimbing menggunakan metode eksperimen dan metode proyek dengan kemampuan berpikir kritis terhadap hasil belajar siswa. 5). Mengetahui adakah interaksi antara pendekatan inkuiri terbimbing menggunakan metode eksperimen dan metode proyek dengan kreativitas terhadap hasil belajar siswa. 6). Mengetahui adakah interaksi antara kemampuan berpikir kritis dan kreativitas terhadap hasil belajar siswa. 7). Mengetahui adakah interaksi antara pendekatan inkuiri terbimbing menggunakan metode eksperimen dan metode proyek dengan kemampuan berpikir kritis dan kreativitas terhadap hasil belajar siswa. Penelitian ini merupakan penelitian eksperimen dengan desain faktorial $2 \times 2 \times 2$. Hasil dari penelitian :1) Ada perbedaan hasil belajar antara siswa yang mendapatkan pembelajaran dengan inkuiri terbimbing menggunakan metode eksperimen dan metode proyek dengan $\mathrm{F}_{\mathrm{obs}}=12.208>\mathrm{F}_{\alpha}=$ $4,02,2)$ Ada perbedaan hasil belajar siswa antara kemampuan berpikir kritis tinggi dan rendah dengan $F_{\mathrm{obs}}=$ $7.826>\mathrm{F}_{\alpha}=4,023$ ) Ada perbedaan hasil belajar siswa antara kreativitas tinggi dan rendah dengan $\mathrm{F}_{\mathrm{obs}}=7.600>$ $\mathrm{F}_{\alpha}=4,02$ 4) Ada interaksi antara inkuiri terbimbing menggunakan metode eksperimen dan metode proyek dengan kemampuan berpikir kritis dengan $F_{\text {obs }}=4.564>F_{\alpha}=4,02$. 5) Ada interaksi antara inkuiri terbimbing menggunakan metode eksperimen dan metode proyek dengan kreativitas dengan $F_{o b s}=8.061>F_{\alpha}=4,02$. 6) Ada interaksi antara kemampuan berpikir kritis dan kreativitas dengan $F_{o b s}=8.910>F_{\alpha}=4,02$. 7) Ada interaksi antara inkuiri terbimbing menggunakan metode eksperimen dan metode proyek dengan kemampuan berpikir kritis dan kreativitas dengan $F_{o b s}=5.122>F_{\alpha}=4,02$.
\end{abstract}

Kata kunci: Penelitian Eksperimen, Inkuiri Terbimbing, Metode Eksperimen, Metode Proyek, Kemampuan Berpikir Kritis dan Kreativitas.

\section{Pendahuluan}

Keberhasilan suatu bangsa salah satunya terletak pada mutu pendidikan yang dapat meningkatkan kualitas sumber daya manusia. Mutu pendidikan mempunyai peran penting dalam kehidupan individu, berbangsa maupun bernegara. Pendidikan adalah proses manusia mengenali diri dengan potensi yang dimiliki, memahami apa yang sedang dihadapi dan mampu menyelesaikan permasalahan dalam kehidupan tanpa harus kehilangan identitas dirinya. Proses pembelajaran disekolah merupakan bagian dari proses pendidikan formal yang bertujuan untuk memberi pengalaman belajar siswa. 
Guru merupakan salah satu pihak yang dapat meningkatkan kualitas sumber daya manusia. Peraturan Menteri Pendidikan Nasional No 47 Tahun 2007 tentang standart proses pendidikan menjelaskan bahwa guru merupakan pendidik profesional dengan tugas utama mendidik, melatih, menilai, dan mengevaluasi peserta didik pada pendidikan anak usia dini jalur pendidikan formal, pendidikan dasar dan pendidikan menengah. Berdasarkan uraian di atas seorang guru sebagai salah satu penunjang dan pelaku dalam pendidikan, sehingga guru dituntut untuk menciptakan pembelajaran yang merangsang siswa mampu menganalisis masalah yang ada dan mencari pemecahan masalah.

Secara bertahap kurikulum yang digunakan di Indonesia mengalami perubahan yang bertujuan untuk menyempurnakan kurikulum, sehingga diharapkan dapat meningkatkan mutu pendidikan nasional. Kurikulum yang digunakan SMA Negeri 4 Kota Madiun dalam pembelajaran adalah Kurikulum Tingkat Satuan Pendidikan (KTSP). Permendiknas RI No 22 Tahun 2006 menjelaskan bahwa untuk mendukung pencapaian tujuan KTSP pengembangan kompetensi siswa di sesuaikan dengan potensi, perkembangan, kebutuhan, dan kepentingan siswa serta tuntutan lingkungan.

Pelajaran fisika merupakan salah pelajaran yang dianggap sulit bagi siswa. Berdasarkan hasil observasi yang dilakukan di SMA 4 kota Madiun diperoleh hasil ulangan harian materi kesetimbangan benda tegar kurang dari KKM seperti yang terdapat pada tabel 1, sehingga materi fisika belum maksimal dikuasai siswa. Berikut ini adalah data nilai rata-rata hasil ulangan harian siswa SMA Negeri 4 Kota Madiun semester genap tahun pelajaran 2014/2015:

Tabel 1. Nilai Ulangan Harian Kesetimbangan Benda Tegar.

\begin{tabular}{ccc}
\hline \multirow{2}{*}{ Kelas } & Rata-Rata Kelas & $\begin{array}{c}\text { Prosentase } \\
(\%)\end{array}$ \\
\cline { 3 - 3 } & & Tidak Tuntas \\
\hline XI IPA 1 & 68,60 & 50 \\
\hline XI IPA 2 & 70,10 & 43 \\
\hline XI IPA 3 & 70,00 & 44 \\
\hline XI IPA 4 & 70,21 & 46 \\
\hline (Sumber: Buku daftar nilai guru fisika)
\end{tabular}

Berdasarkan tabel diatas diperoleh nilai rata-rata ketuntasan $54 \%$ dan tidak tuntas $46 \%$. Hasil wawancara dengan guru mata pelajaran fisika, nilai rata-rata hasil ulangan harian kesetimbangan benda tegar masih dibawah KKM disebabkan karena beberapa permasalahan sebagai berikut: 1) guru menggunakan pembelajaran konseptual dalam penyampaian materi fisika sehingga menimbulkan kejenuhan pada siswa. 2) Kurangnya pemahaman siswa terhadap apa yang diketahui dan yang belum diketahui terhadap materi yg diajarkan. 3) Siswa kurang aktif dalam menggali informasi materi fisika sehingga pengetahuan yang siswa dapatkan hanya berasal dari guru. 4) Guru masih dominan dalam pembelajaran (teacher centered learning) mengakibatkan siswa kurang percaya diri dalam berpendapat. 5) Guru belum memperhatikan model dan metode pembelajaran yang dapat meningkatkan mutu pembelajaran. 6) Guru belum sepenuhnya memperhatikan karakterstik siswa sebagai salah satu penentu keberhasilan siswa.

Berdasarkan hasil observasi diatas, maka diperlukan perbaikan dalam proses pembelajaran fisika. Kondisi tersebut dapat diperbaiki dengan memperhatikan strategi dan metode pembelajaran yang sesuai dengan karakter materi dan karakter siswa. Salah satu strategi yang sesuai dengan karakter pembelajaran fisika khususnya materi fluida yaitu strategi inkuiri terbimbing. Menurut Sanjaya (2013: 196) "Strategi inkuiri adalah rangkaian kegiatan pembelajaran yang menekankan pada proses berpikir secara kritis dan analitis untuk mencari dan menemukan jawaban dari suatu masalah yang dipertanyakan". Implementasi inkuiri terbimbing dalam pembelajaran dapat menggunakan metode eksperimen dan metode proyek.

Implementasi inkuiri terbimbing terbimbing dalam pembelajaran dapat menggunakan metode eksperimen dan metode proyek. Metode eksperimen merupakan cara penyajian pelajaran, di mana siswa melakukan percobaan dengan mengalami dan membuktikan sendiri suatu yang dipelajari (Djamarah, Azwan Zain, 2013: 84). "Metode 
proyek adalah pemberian tugas kepada peserta didik untuk dikerjakan secar individual. Peserta didik dituntut untuk mengamati, membaca, meneliti kemudian di minta untuk membuat laporan dalam bentuk makalah atau produk" (Yamin, 2013: 162). Strategi inkuiri terbimbing dengan metode eksperimen dan metode proyek diharapkan dapat membantu siswa dalam mengaplikasikan teori-teori fisika yang didapat dengan langsung mempraktekannya sehingga menghasilkan sebuah aplikasi baru hasil pengembangan pengetahuan mereka.

Pembelajaran inkuiri terbimbing dengan metode eksperimen dan metode proyek cocok diterapkan dalam pembelajaran fisika karena pembelajaran fisika tidak hanya mempelajari prinsip, hukum, dan konsep, namun diberikan aplikasi-aplikasi yang dapat mereka kembangkan untuk kemajuan teknologi. Metode eksperimen dan metode proyek diharapkan dapat membantu siswa dalam mengaplikasikan teori-teori fisika yang didapat dengan langsung mempraktekannya sehingga menghasilkan sebuah aplikasi baru hasil pengembangan pengetahuan mereka.

Keberhasilan pembelajaran fisika selain dipengaruhi pendekatan dan metode pembelajaran juga dipengaruhi oleh faktor internal siswa. Dalam penelitian ini melihat dari kreativitas daan kemampuan berpikir kritis. Penalaran dan pemahaman dalam materi ini menuntut siswa berfikir kreatif agar dapat menerapkanya dalam penyelesaian permasalahan. Siswa yang memiliki kreativitas tinggi selalu ingin tahu, memiliki minat yang tinggi, menyukai aktifitas yang kreatif. Siswa yang memiliki kemampuan yang kreatif tidak hanya menerima informasi dari guru saja melainkan berusaha mencari dan memberikan informasi dalam proses belajar secara mandiri.

Penelitian ini bertujuan untuk: 1) Mengetahui adakah perbedaan hasil belajar antara siswa yang diberi pembelajaran dengan pendekatan inkuiri terbimbing menggunakan metode eksperimen dan metode proyek. 2) Mengetahui adakah perbedaan hasil belajar antara siswa yang memiliki kemampuan berpikir kritis tinggi dan kemampuan berpikir kritis rendah. 3) Mengetahui adakah perbedaan hasil belajar antara siswa yang memiliki kreativitas tinggi dan kreativitas rendah. 4) Mengetahui adakah interaksi antara pendekatan inkuiri terbimbing menggunakan metode eksperimen dan metode proyek dengan kemampuan berpikir kritis terhadap hasil belajar siswa. 5) Mengetahui adakah interaksi antara pendekatan inkuiri terbimbing menggunakan metode eksperimen dan metode proyek dengan kreativitas terhadap hasil belajar siswa. 6) Mengetahui adakah interaksi antara kemampuan berpikir kritis dan kreativitas terhadap hasil belajar siswa. 7) Mengetahui adakah interaksi antara pendekatan inkuiri terbimbing menggunakan metode eksperimen dan metode proyek dengan kemampuan berpikir kritis dan kreativitas terhadap hasil belajar siswa.

\section{Metode Penelitian}

Penelitian ini dilakukan di XI IPA SMA Negeri 4 Kota Madiun tahun pelajaran 2014/2015. Pelaksanaan penelitian ini dilakukan secara bertahap dan sesuai dengan tahapan-tahapan penelitian yang telah disusun. Adapun tahap-tahap pelaksanaannya yaitu 1) Tahap persiapan, meliputi: pengajuan judul tesis, permohonan pembimbing, pembuatan proposal, pembuatan instrumen, perijinan penelitian kepala lembaga terkait, konsultasi instrumen penelitian, dan validasi instrumen, 2) Tahap penelitian, yaitu semua kegiatan yang dilaksanakan di tempat penelitian, meliputi: uji instrumen penelitian dan pengambilan data yang disesuaikan dengan alokasi waktu penyampaian materi termofisika. 3) Tahap penyelesaian, meliputi: pengolahan data dan penyusunan laporan tesis

Teknik pengambilan data dilakukan dengan pemberian tes, observasi, angket dan dokumentasi. Data hasil belajar siswa diperoleh dari hasil tes kognitif. Pada angket kreativitas dan tes kemampuan berpikir kritis diperoleh setelah proses pembelajaran, bertujuan untuk mengetahui kreativitas dan kemampuan berpikir kritis yang dimiliki siswa. Sedangkan metode observasi dan dokumentasi diperoleh pada saat proses pembelajaran dan praktikum 
berlangsung. Metode observasi dilakukan untuk mengambil data hasil belajar afektif dan psikomotor.

Uji validitas pada tes hasil belajar kognitif dilakukan untuk mengetahui apakah alat evaluasi itu layak digunakan. Hasil soal kognitif uji coba kemudian dihitung validitas, reliabilitas, daya beda soal, indeks kesukaran, validitas dan reliabilitas. Sedangkan tes kemampuan berpikir kritis dan angket kreativitas dihitung validitas dan reliabilitas. Teknik analisis data pada penelitian ini terdiri dari uji prasyarat dan uji hipotesis. Pada uji prasyarat meliputi uji normalitas dan uji homogenitas. Pada uji hipotesis data penelitian menggunakan uji Anava $2 \times 2 \times 2$.

\section{Hasil Penelitian dan Pembahasan}

Berdasarkan hasil uji normalitas dan homogenitas didapatkan kesimpulan bahwa data yang diperoleh terdistribusi normal dan varian datanya homogen. Karena uji normalitas dan homogenitas telah dipenuhi kemudian dilakukan uji anava. Hasil uji hipotesis seperti pada tabel 2 dibawah ini:

Tabel 2. Hasil Uji Anava

\begin{tabular}{lcc}
\hline \multicolumn{1}{c}{ Source } & F & Sig. \\
\hline Metode & 12.208 & .001 \\
Kemampuan_Berpikir_Kritis & 7.826 & .007 \\
Kreativitas & 7.600 & .008 \\
Metode * & 4.564 & .037 \\
Kemampuan_Berpikir_Kritis & 8.061 & .006 \\
$\begin{array}{l}\text { Metode * Kreativitas } \\
\text { Kemampuan_Berpikir_Kritis* }\end{array}$ & 8.910 & .004 \\
$\begin{array}{l}\text { Kreativitas } \\
\text { Metode * }\end{array}$ & & \\
$\begin{array}{l}\text { Kemampuan_Berpikir_Kritis* } \\
\text { Kreativitas }\end{array}$ & 5.122 & .028 \\
\hline
\end{tabular}
bahwa:

Hasil analisis tabel 2 dapat disimpulkan

1. Hipotesis pertama: Perbedaan hasil belajar antara siswa yang mendapatkan pembelajaran dengan inkuiri terbimbing menggunakan metode eksperimen dan metode proyek.

Hasil perhitungan yang dilakukan menggunakan SPSS 17 menunjukkan $\mathrm{H}_{0 \mathrm{~A}}$ ditolak dan $\mathrm{H}_{1 \mathrm{~A}}$ diterima karena nilai $\mathrm{F}_{\mathrm{obs}}>$ $\mathrm{F}_{\text {tabel. }}$. Nilai $\mathrm{F}_{\text {obs }}$ kelas eksperimen I dan kelas eksperimen II terhadap hasil belajar sebesar 12.208 sedangkan untuk $F_{\text {tabel }}$ sebesar 4,02. Berdasarkan hasil analisis data yang diperoleh dapat disimpulkan bahwa hasil penelitian sesuai dengan hipotesis yaitu ada perbedaan pembelajaran inkuiri terbimbing menggunakan metode eksperimen dan metode proyek terhadap hasil belajar siswa.

Penggunaan pembelajaran inkuiri terbimbing dengan metode proyek menghasilkan hasil belajar fisika yang lebih baik daripada penggunaan pembelajaran inkuiri terbimbing dengan metode eksperimen. Pada pembelajaran fisika dengan inkuiri terbimbing menggunakan metode proyek, guru memberikan kebebasan penuh kepada siswa untuk mengembangkan pola pikirnya. Siswa menjadi lebih paham konsep suatu materi apabila dalam proses pembelajaran tersebut menemukan sendiri atau mengalami secara langsung sehingga pengetahuannya dapat melekat dalam pikiran siswa.

Siswa juga mengalami proses ilmiah secara langsung mulai mengamati, mengidentifikasi, mengobservasi, menganalisis dan menyimpulkan sendiri permasalahan, yang mana pemahaman yang diperoleh dengan pengalaman secara langsung jauh lebih efektif.

Hal ini berbeda dengan pembelajaran fisika dengan inkuiri terbimbing menggunakan metode eksperimen. Pada metode eksperimen siswa secara kelompok melakukan percobaan dengan mempergunakan alat atau waktu lebih dari satu kali dengan mengalami dan membuktikan sendiri suatu yang dipelajari, jadi metode eksperimen lebih menekankan pada pelibatan secara langsung siswa untuk mengalami proses dan membuktikan sendiri hasil percobaan.

Penelitian ini sesuai dengan hasil penelitian dari Akinoglu, O (2008), menunjukkan bahwa pembelajaran inkuiri terbimbing berbasis proyek meningkatkan minat siswa terhadap ilmu pengetahuan dan teknologi, terbukti dengan meningkatnya hasil belajar siswa. Penelitian relevan yang lainnya dari Sadeh \& Michal Zion (2012). Pada penelitian tersebut menunjukkan bahwa ada 
perbedaan hasil belajar siswa antara inkuiri terbimbing dengan metode proyek dan open inkuiri.

Berdasarkan penjelasan beberapa penelitian tersebut dapat diperoleh penjelasan bahwa pembelajaran inkuiri terbimbing dengan metode proyek meningkatkan hasil belajar siswa dibandingkan dengan metode eksperimen. Jadi ada perbedaan pengaruh pembelajaran inkuiri terbimbing menggunakan metode eksperimen dan metode proyek terhadap hasil belajar siswa.

2. Hipotesis kedua: Perbedaan hasil belajar siswa antara kemampuan berpikir kritis tinggi dan rendah.

Berdasarkan hasil analisis menunjukkan $F_{\text {obs }}$ adalah 7,826 sedangkan untuk $F_{\text {tabel }}$ sebesar 4,02 sehingga $F_{\text {obs }}>F_{\text {tabel }}$ maka $H_{0 A}$ ditolak dan $\mathrm{H}_{1 \mathrm{~A}}$ diterima. Hasil penelitian sesuai dengan hipotesis yaitu ada perbedaan hasil belajar siswa antara kemampuan berpikir kritis tinggi dan kemampuan berpikir kritis rendah. Pada penelitian ini kemampuan berpikir kritis berpengaruh terhadap hasil belajar. Siswa yang memiliki kemampuan berpikir kritis tinggi memperoleh hasil belajar yang lebih tinggi dibanding dengan siswa yang memiliki kemampuan berpikir kritis rendah. Hal ini disebabkan siswa yang mempunyai kemampuan berpikir kritis tinggi mampu menganalisis suatu masalah melalui evaluasi potensi, pemecahan masalah, dan sintesis informasi untuk menentukan keputusan, Berbeda dengan siswa yang mempunyai kemampuan berpikir kritis rendah cenderung pasif dan malas dalam mengikuti pelajaran sehingga cenderung kurang dapat memahami apa yang disampaikan oleh guru.

Penelitian ini sesuai dengan penelitian dari Li-Fang, Zhang (2011). Pada penelitian tersebut menunjukkan bahwa ada perbedaan kemampuan berpikir kritis tinggi dan rendah. Sehingga dapat diperoleh penjelasan bahwa kemampuan berpikir kritis siswa berpengaruh terhadap proses pembelajaran dan menentukan hasil belajar.

Berdasarkan uraian penelitian tersebut dapat diperoleh penjelasan bahwa kemampuan berpikir kritis siswa berpengaruh terhadap proses pembelajaran dan menentukan hasil belajar, jadi ada perbedaan antara kemampuan berpikir kritis tinggi dan rendah terhadap hasil belajar.

3. Hipotesis ketiga: Perbedaan hasil belajar siswa antara kreativitas tinggi dan rendah.

Hasil analisis menunjukkan $\mathrm{F}_{\mathrm{obs}}$ adalah 7,6 sedangkan untuk $F_{\text {tabel }}$ sebesar 4,02 sehingga $\mathrm{F}_{\mathrm{obs}}>\mathrm{F}_{\text {tabel }}$ maka $\mathrm{H}_{0 \mathrm{c}}$ ditolak dan $\mathrm{H}_{1 \mathrm{c}}$ diterima. Hasil penelitian sesuai dengan hipotesis yaitu ada perbedaan antara kreativitas tinggi dan rendah terhadap hasil belajar siswa. Kreativitas berpengaruh terhadap hasil belajar. Siswa yang mempunyai kreativitas tinggi dapat menciptakan gagasan baru dari angan-angan, ingatan, keterangan dan konsep yang dimilikinya, sehingga dapat melahirkan ide-ide yang sesuai dengan konsep ilmiah, dengan demikian dapat tercipta pula sesuatu yang baru yang sesuai dengan konsep fisika. Siswa yang kreatif juga akan mempunyai mental dan kepribadian yang tangguh dalam melakukan suatu percobaan, sedangkan siswa yang mempunyai kreativitas rendah cenderung pasif dalam mengikuti pelajaran sehingga kurang memahami apa yang disampaikan oleh guru, dengan perbedaan ini maka penguasaan terhadap materi pelajaran bagi siswa yang memiliki kreativitas tinggi lebih baik dibandingkan siswa yang memiliki kreativitas rendah.

Penelitian ini sesuai dengan penelitian dari Lampert, Nancy (2006). Hasil penelitian ini menyimpulkan bahwa siswa yang memiliki kreativitas tinggi memiliki banyak ide untuk mendapatkan solusi tentang permasalahan yang diberikan guru. Guru juga berperan dalam menumbuhkan kreativitas siswa..

Berdasarkan kesimpulan penelitian di atas dapat diperoleh penjelasan bahwa kreativitas siswa berpengaruh terhadap proses pembelajaran dan menentukan hasil belajar siswa, jadi ada perbedaan antara kreativitas tinggi dan rendah terhadap hasil belajar siswa.

4. Hipotesis keempat: Interaksi antara inkuiri terbimbing melalui metode eksperimen dan proyek dengan kemampuan berpikir kritis terhadap hasil belajar siswa. 
Hasil analisis menunjukkan bahwa Harga $\mathrm{F}_{\text {obs }} 4,564>$ dari $\mathrm{F}_{\text {tabel }} 4,02$ berarti bahwa $\mathrm{H}_{0}$ ditolak dan $\mathrm{H}_{01}$ diterima, sehingga ada interaksi antara inkuiri terbimbing melalui metode eksperimen dan proyek dengan kemampuan berpikir kritis terhadap hasil belajar siswa. Kelas eksperimen I menggunakan pembelajaran inkuiri terbimbing dengan metode eksperimen menunjukkan bahwa siswa yang memiliki kemampuan berpikir kritis tinggi mendapatkan hasil belajar fisika lebih baik dari pada dari pada siswa yang memiliki kemampuan berpikir kritis rendah. Kelas eksperimen II menggunakan pembelajaran inkuiri terbimbing dengan metode proyek menunjukkan bahwa siswa yang memiliki kemampuan berpikir kritis tinggi mendapatkan hasil belajar fisika lebih baik dari pada dari pada siswa yang memiliki kemampuan berpikir kritis rendah.

Metode pembelajaran dan kemampuan berpikir kritis bersama-sama memberikan pengaruh yang signifikan terhadap hasil belajar. Interaksi yang muncul adalah siswa yang memiliki kemampuan berpikir kritis tinggi baik diberikan pembelajaran inkuiri terbimbing dengan metode eksperimen maupun metode proyek memiliki hasil belajar yang lebih baik dibandingkan dengan siswa yang memiliki kemampuan berpikir kritis rendah.

Penelitian ini sesuai dengan hasil oleh McMullen, Maureen A (2015). Pada penelitian tersebut menunjukkan bahwa Ada perbedaan antara kemampuan berpikir kritis tinggi dan rendah. Dibuktikan dengan hasil postest dan pretest terdapat peningkatan hasil belajar. Kemampuan berpikir kritis memiliki peran penting dalam proses pembelajaran. Siswa yang memiliki kemampuan berpikir kritis mampu menganalisis suatu masalah melalui evaluasi potensi, pemecahan masalah, dan sintesis informasi untuk menentukan keputusan sehingga siswa yang memiliki kemampuan berpikir kritis tinggi.

Penelitian lain yang relevan adalah dari Gunn, Thelma M; Grigg, Lance M; Pomahac, Guy A (2015) menyimpulkan bahwa siswa yang memiliki kemampuan berpikir kritis mampu menganalisis suatu masalah melalui evaluasi potensi, pemecahan masalah, dan sintesis informasi untuk menentukan keputusan sehingga siswa yang memiliki kemampuan berpikir kritis mampu mendapatkan hasil belajar yang lebih baik.

Berdasarkan penjelasan penelitian di atas dapat diperoleh kesimpulan bahwa metode pembelajaran dan kemampuan berpikir kritis siswa berpengaruh terhadap proses pembelajaran dan menentukan hasil belajar, sehingga ada interaksi antara siswa inkuiri terbimbing menggunakan metode eksperimen dan metode proyek dengan kemampuan berpikir kritis terhadap hasil belajar.

5. Hipotesis kelima: Interaksi antara inkuiri terbimbing melalui metode eksperimen dan proyek dengan kreativitas terhadap hasil belajar siswa.

Hasil analisis menunjukkan $\mathrm{H}_{0 \mathrm{Ac}}$ di tolak dan $\mathrm{H}_{1 \mathrm{Ac}}$ diterima karena nilai $\mathrm{F}_{\mathrm{obs}}>$ $\mathrm{F}_{\text {tabel. }}$. Berdasarkan tabel 4.15 hasil anava untuk interaksi (AC) menunjukkan hasil statistik uji $\mathrm{F}_{\text {obs }}$ sebesar 8.061 sehingga lebih besar dari $\mathrm{F}_{\text {tabel }}$ 4,02 berarti bahwa $\mathrm{H}_{0}$ ditolak dan $\mathrm{H}_{1}$ diterima, maka dapat disimpulkan bahwa ada interaksi antara inkuiri terbimbing melalui metode eksperimen dan proyek dengan kreativitas terhadap hasil belajar siswa. Pada kelas eksperimen I dan kelas eksperimen II menunjukkan bahwa siswa yang memiliki kreativitas tinggi mendapatkan hasil belajar fisika lebih baik dari pada siswa yang memiliki kreativitas rendah.

Kreativitas adalah cara berpikir dimulai dari mengidentifikasi suatu masalah, memperdalam masalah dengan mencari informasi menyangkut masalah tersebut, menimbulkan sebuah ide baru dari beberapa informasi yang didapat, kemudian membuktikan dan mengimplementasikan ide tersebut. Penggunaan metode proyek memberikan kebebasan penuh kepada siswa untuk menggunakan kreativitasnya dalam menyelesaikan masalah yang mereka temukan sendiri sehingga siswa dengan kreativitas tinggi akan lebih mudah dalam menerima informasi. Ketika menggunakan metode eksperimen guru membimbing siswa dalam penyelesaian masalah, siswa yang mempunyai kreativitas rendah dapat menerima informasi 
karena mendapat petunjuk penyelesaian dari guru. Interaksi yang muncul adalah metode proyek lebih baik jika digunakan dalam pembelajaran pada siswa yang memiliki kreativitas tinggi, sedangkan metode eksperimen lebih baik jika digunakan dalam pembelajaran pada siswa yang memiliki kreativitas rendah.

Penelitian ini sesuai dengan hasil penelitian dari Aktamis, $\mathrm{H}$ dan Omer Ergin (2008), menyimpulkan bahwa ada perbedaan pada kreativitas siswa sekolah dasar.

Berdasarkan kesimpulan penelitian di atas dapat diperoleh penjelasan bahwa pada kelas eksperimen I menunjukkan bahwa siswa yang memiliki kreativitas tinggi mendapatkan hasil belajar fisika lebih baik dari pada siswa yang memiliki kreativitas rendah, sedangkan pada kelas eksperimen II menunjukkan bahwa siswa yang memiliki kreativitas tinggi mendapatkan hasil belajar fisika lebih baik dari pada dari pada siswa yang memiliki kreativitas rendah, jadi ada Interaksi antara inkuiri terbimbing menggunakan metode eksperimen dan metode proyek dengan kreativitas terhadap hasil belajar siswa.

6. Hipotesis keenam: Interaksi antara kemampuan berpikir kritis dan kreativitas terhadap hasil belajar siswa.

Hasil analisis data menunjukkan ada interaksi antara kemampuan berpikir kritis dan kreativitas terhadap hasil belajar siswa, karena harga $\mathrm{F}_{\text {obs }} 8.910$ lebih besar dari $\mathrm{F}_{\text {tabel }} 4,02$. Hasil ini merupakan konsekuensi dari dua keputusan sebelumnya yaitu secara parsial dan secara signifikan kemampuan berpikir kritis dan kreativitas memberikan pengaruh yang positif terhadap hasil belajar.

Siswa yang mempunyai kemampuan berpikir kritis tinggi dan kreativitas tinggi dalam setiap proses pembelajarannya lebih baik dibandingkan dengan kelompok siswa yang lain. Kemampuan berpikir kritis yang tinggi menjadi modal utama untuk dapat menyelesaikan permasalahan dalam bentuk tes ataupun nontes. Kreativitas tinggi membantu menyelesaikan masalah pada materi fluida statis dengan cara yang baru dan kreatif. Penelitian ini dilakukan pada siswa yang mempunyai latar belakang yang heterogen, sehigga baik siswa yang mempunyai tingkat kemampuan berpikir kritis tinggi atau rendah dan tingkat kreativitas tinggi atau rendah dapat mengerjakan soal yang diberikan guru dan menyelesaikan tugas-tugas dengan baik. Selain itu, adanya kerjasama yang baik dalam menyelesaikan tugas kelompok. Adanya kekompakan siswa dalam menyelesaikan tugas, secara tidak langsung dapat memotivasi siswa yang memiliki kemampuan berpikir kritis rendah dan kreativitas rendah.

Berdasarkan uraian diatas dapat disimpulkan bahwa ada interaksi antara kemampuan berpikir kritis dengan kreativitas terhadap hasil belajar siswa.

7. Hipotesis ketujuh: Interaksi antara inkuiri terbimbing melalui metode eksperimen dan proyek dengan kemampuan berpikir kritis dan kreativitas terhadap hasil belajar siswa.

Hasil analisis data menunjukkan ada interaksi antara inkuiri terbimbing menggunakan metode eksperimen dan metode proyek dengan kemampuan berpikir kritis dan kreativitas terhadap hasil belajar siswa. $F_{\text {obs }}$ 5.122 lebih besar dari $F_{\text {tabel }} 4,02$, sehingga dapat disimpulkan bahwa ada interaksi antara inkuiri terbimbing melaui metode eksperimen dan metode proyek dengan kemampuan berpikir kritis dan kreativitas terhadap hasil belajar siswa.

Pada deskripsi data menjelaskan bahwa siswa yang mempunyai kemampuan berpikir kritis tinggi dan kreativitas tinggi jika diberi pendekatan inkuiri terbimbing melalui metode proyek memperoleh rata-rata hasil belajar lebih baik dibandingkan yang diajar dengan pendekatan inkuiri terbimbing melalui metode eksperimen. Penelitian yang relevan dari Josef Trna (2012). Penelitian tersebut menunjukkan ada perubahan yang signifikan mengenai hasil belajar siswa setelah diterapkannya inkuiri terbimbing terhadap gaya belajar siswa, dengan penerapan metode proyek dalam pembelajaran maka hasil belajar siswa meningkat.

Berdasarkan uraian di atas dapat disimpulkan bahwa ada interaksi antara inkuiri terbimbing melalui metode eksperimen 
dan proyek, kemampuan berpikir kritis dan kreativitas terhadap hasil belajar siswa.

\section{Kesimpulan dan Rekomendasi}

Berdasarkan hasil analisis dan pengujian hipotesis yang telah dipaparkan, dapat disimpulkan 1). Ada perbedaan hasil belajar antara siswa yang diberi pembelajaran dengan pendekatan inkuiri terbimbing menggunakan metode eksperimen dan metode proyek, karena $\mathrm{F}_{\mathrm{obs}}=12.208>\mathrm{F}_{\alpha}=4,02.2$ ) Ada perbedaan hasil belajar antara siswa yang memiliki kemampuan berpikir kritis tinggi dan kemampuan berpikir kritis rendah, karena $\mathrm{F}_{\mathrm{obs}}=7.826>\mathrm{F}_{\alpha}=4,02$. 3) Ada perbedaan hasil belajar antara siswa yang memiliki kreativitas tinggi dan kreativitas rendah, karena $F_{\text {obs }}=7.600>F_{\alpha}=4,02$. 4) Ada interaksi antara pendekatan inkuiri terbimbing menggunakan metode eksperimen dan metode proyek dengan kemampuan berpikir kritis terhadap hasil belajar siswa, karena $\mathrm{F}_{\mathrm{obs}}=$ $4.564>\mathrm{F}_{\alpha}=4,02$. 5) Ada interaksi antara pendekatan inkuiri terbimbing melalui metode eksperimen dan proyek dengan kreativitas tinggi atau rendah menunjukan adanya perbedaan pengaruh yang signifikan terhadap hasil belajar siswa karena $\mathrm{F}_{\mathrm{obs}}=4.564>\mathrm{F}_{\alpha}=$ 4,02. 6) Ada interaksi antara kreativitas dan kemampuan berpikir kritis menunjukkan adanya perbedaan pengaruh yang signifikan terhadap hasil belajar siswa, karena $\mathrm{F}_{\text {obs }}=$ $8.910>\mathrm{F}_{\alpha}=4,02.7$ ) Ada interaksi antara pendekatan inkuiri terbimbing menggunakan metode eksperimen dan metode proyek dengan kemampuan berpikir kritis dan kreativitas terhadap hasil belajar siswa karena $\mathrm{F}_{\text {obs }}=$ $5.122>\mathrm{F}_{\alpha}=4,02$. Berdasarkan simpulan dan implikasi hasil penelitian, sebagai perbaikan dan peningkatan dalam pembelajaran fisika saran dari peneliti adalah: 1). Manajemen waktu yang baik dan persiapan menggunakan praktikum dalam pembelajaran pada penerapan metode pembelajaran yang digunakan dalam pembelajaran, khususnya metode eksperimen dan proyek akan memberikan dampak positif terhadap hasil belajar pada aspek kognitif, afektif dan psikomotor. 2). Perumusan masalah dan langkah kerja pada inkuiri terbimbing melalui metode eksperimen dan proyek harus diinformasikan kepada siswa secara jelas dan terarah, agar siswa dapat menjalani proses pembelajaran dengan baik. 3). Perlu dilakukan penelitian tentang faktor-faktor lain yang berpengaruh terhadap hasil belajar, sehingga dapat menambah pengetahuan guru dalam upaya meningkatkan hasil belajar siswa. 5). Hasil penelitian ini dapat digunakan sebagai acuan untuk penelitian-penelitian berikutnya yang sejenis dan hasil penelitian ini diharapkan dapat memberikan kontribusi bagi perkembangan ilmu pengetahuan khususnya mata pelajaran fisika. 6). Skala angket kreativitas hendaklah dibuat empat tingkatan saja yaitu selalu, sering, kadang-kadang/jarang dan tidak pernah, karena antara kadang-kadang dan jarang perbedaanya sangat tipis sehingga menyulitkan responden untuk memilih satu diantara dua jawaban tersebut.

\section{Daftar Pustaka}

Aktamis, H \& Omer Ergin. (2008). The Effect of Scientific Prosess Skills Education on Students' Scientific Creativity, Science Attitudes and Acedemic Archievements. Asia-Pacific Forum, 9 (4), 1-21.

Akinoglu, O. (2008). Assessment Of The InquiryBased Project Implementation Process In Science Education Upon Students' Points Of Views. International journal of instruction, 1(1).

Djamarah, S B \& Zain.(2013). Strategi Belajar Mengajar. Jakarta: Rineka Cipta.

Eragamreddy, N.. (2013). Teaching Creative Thinking Skills. Internatonal journal of English language. (1).

Gunn, Thelma M; Grigg, Lance M; Pomahac, Guy A. (2008). Can Bioethical Issues and Questioning Strategies Increase Scientific Understandings. Critical Thinking in Science Education: (42).

Lampert\&Nancy. (2006). Enhancing critical thinking with aesthetic, critical, and creative inquiry. Jurnal Internasional. (59)

McMullen \& Maureen A.. (2008). Examining Patterns of Change in the Critical Thinking 
ISSN: 2252-7893, Vol. 6, No. 3, 2017 (hal 77-86)

http://jurnal.uns.ac.id/inkuiri

Skills of Graduate Nursing Student. The journal of nursing education.

Li-Fang Zhang. (2013). Contributions of Thinking Styles to Critical Thinking Dispositions. International journal of humanities and social science.

Peraturan Menteri Pendidikan Nasional No 47 Tahun (2007). Standart Proses Pendidikan. Jakarta: Kementrian Pendidikan dan Kebudayaan.

Peraturan Menteri Pendidikan Nasional Republik Indonesa No 22 Tahun (2006). Standart Isi untuk Satuan Pendidikan Dasar dan Menengah.Jakarta: Kementrian Pendidikan dan Kebudayaan

Sadeh, I \& Zion,M. (2012). Which Type of Inquiry Project Do High School Biology Students Prefer: Open or Guided. Science Business Media. 1 (2).

Sanjaya, W. (2013). Strategi Pembelajaran Berorientasi Standar Proses Pendedikan. Jakarta: Preanada media group.

Trna. J. (2012). Implementation Of Inquiry-Based Science Education In Science Teacher Training. Journal of educational and instructional Student In the world (2).

Yamin, M. (2013). Strategi dan Metode dalam Pembelajaran. Jakarta: Referensi. 
JURNAL INKUIRI

ISSN: 2252-7893, Vol. 6, No. 3, 2017 (hal 77-86)

http://jurnal.uns.ac.id/inkuiri 